\title{
ХРИСТИАНСКАЯ ТЕОЛОГИЧЕСКАЯ АКАДЕМИЯ В ВАРШАВЕ: ОПЫТ МЕЖРЕЛИГИОЗНОГО ДИАЛОГА
}

\section{Л. Ю. МАЛЫХИНА}

\section{Брестский государственный технический университет, г. Брест, Беларусь}

Трудности во взаимоотношениях христианских конфессий на территории Второй Речи Посполитой являются хрестоматийным примером ущемления прав религиозных меньшинств в случае, если одна их церквей конституционно признаётся государственной. Иногда именно это обстоятельство способствует диалогу и сотрудничеству между собой представителей религиозных меньшинств. Наше исследование посвящено изучению положительного опыта межрелигиозного сотрудничества христианских церквей в сфере образования. Христианская теологическая академии в Варшаве является государственным межконфессиональным высшим учебным заведением, которое подчиняется Министерству народного образования Польши.

Предысторией создания вуза считают функционирование в Варшавском университете после возрождения польской государственности кафедры католического богословия (1918), факультета евангелической теологии (1922) и курсов по изучению православного богословия (польск. Studium Teologii Prawosławne). Православное отделение подготовило с 1925 по 1939 гг. 318 специалистов [1]. Среди них - архиепископ Буэнос-Айресский и Аргентинский Афанасий (Мартос). Уже в межвоенный период изучение богословия в Варшавском университете начинало приобретать экуменическое измерение : в целях налаживания межцерковного диалога представители христианских направлений участвовали в совместных службах и церемониях, где молились за единство христиан, а также в других формах приходской жизни изучали историю и духовное богатство других церквей.

После окончания Второй мировой войны в 1954 г., выйдя из стен Варшавского университета, начинают раздельное существование Академия католического богословия (Akademię Teologii Katolickiej) и Христианская теологическая академия (польск. Chrześcijańska Akademia Teologiczna w Warszawie, ChAT), преобразованная из факультета евангелической теологии. Отделение православного богословия в университете закрывается. Первыми ректорами ChAT были протестантские пасторы - лютеране: Виктор Немчик (19541965); Вольдемар Гастпари (1965-1981); Ян Богуслав Немчик (1981-1987). Ежи Грыняков (1987-1990).

С 1954 г. и до запрета коммунистическим правительством в 1965 г. в деятельности ChAT также принимала участие старокатолическая церковь (Kościół Starokatolicki w RP). Co второй половины 1950-х до 1989 г. в структуре академии находились: факультет евангелической теологии, факультет старокатолического богословия, с 1957 г. - факультет православного богословия. Таким образом, ChАТ стал единственным в своем роде экуменическим университетом, который обладая всеми научными полномочиями, готовил кадры для нужд религиозных меньшинств [2, с. 8].

Политические преобразования после 1989 г. позволили богословским университетам расширить степень своей автономии и независимости. В 1991 г. руководство ChAT разработало новый устав университета, правила обучения, организационного и студенческого самоуправления, утвердило символ (фото 1). Эти документы определили объём компетенций и ответственности руководства и сотрудников, обеспечили взаимодействие преподавателей и студентов в принятии наиболее важных решений, касающихся университета. Научная, педагогическая и организационная деятельность теологической Академии приобрела динамику, что способствовало росту её авторитета как внутри страны, так и за рубежом.

Академия оперативно отреагировала на изменения и образовательные потребности постсоветской Польши. Так, после возвращения к обязательному преподаванию религии в школе в 1991/1992 уч. г., в рамках Академии был создан Экуменический педагогический и катехетический институт. Главная его цель заключалась в подготовке кадров катехизаторов, 
которые могли бы преподавать в школах не только религию, но и другие общеобразовательные дисциплины. В июне 1995 г. первые выпускники этого института получили дипломы магистров теологии в области религиозной педагогики.

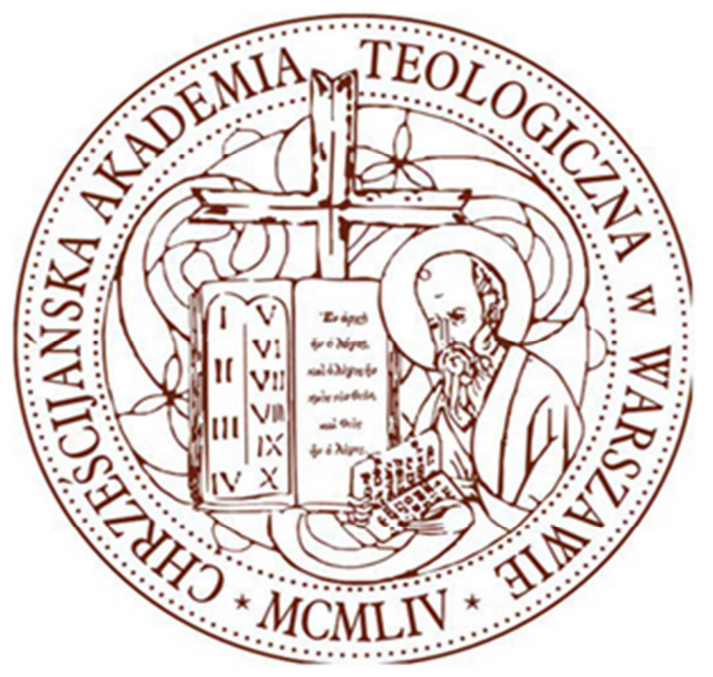

\section{Рисунок 1 - Символ Христианской теологической академии в Варшаве}

Спустя какое-то время Институт был преобразован в Экуменический педагогический институт, при нём открылся трёхлетний бакалавриат профессионального обучения по двум специальностям в области педагогики. В 1996/1997 учебном году первые студенты были приняты на обучение по направлению «Социальная работа», через год была введена вторая специальность - «Школьная и коррекционная педагогика».

С 1999/2000 учебного года выпускникам иных высших профессиональных учебных заведений также получили здесь возможность получить дополнительную специальность после двухлетнего обучения по магистерским программам.

Академия имеет современную образовательную и спортивную инфраструктуру. В очной, заочной и вечерней форме студенты двух факультетов - социальных наук и теологии получают по окончании вуза квалификации по специальностям «Дошкольное и начальное образование», «Педагогика», «Социальная работа», «Теология».

Факультет теологии, который проводит исследования по направлениям: исследования первого цикла в области евангелического, православного, старокатолического и протестантского богословия; исследования второго цикла по евангелическому, православному, старокатолическому богословию и религиозным традициям. «СhАТ - это своего рода лаборатория широко понимаемого экуменического взаимодействия, пересекающего конфессиональные, социальные и национальные границы. Является центром развития религиозных и нерелигиозных научных исследований, критических богословских размышлений, в которых всегда нуждалась Церковь. Поэтому многие религиозные меньшинства стремились к тому, чтобы польское государство в партикулярных законах гарантировало им право обучения своих кадров в этом университете» [2, с. 9].

С 1990 г. ректорами академии стали избираться представители от различных конфессий с определённой периодичностью: епископ Виктор Высочанский - польский католик (1990-1996), православный архиепископ Иеремиас Ян Анчимюк (1996-2002), польский католик епископ Виктор Высочанский (2002-2008), православный архиепископ Иеремиас Ян Анчимюк (2008-2012). С 2012 г. академию возглавляет священник Богуслав Милерский (фото 2).

Увеличение в штате количества профессоров со значительными научными достижениями позволило 1 марта 1994 г. принять решение об учреждении докторантуры по богословским наукам. Сегодня оба факультета имеют право присуждать учёную степень доктора, а теологический факультет дополнительно проводить абилитащию - лечебные, педагогические, психологические и социальные мероприятия по отношению к инвалидам или психологически травмированным людям, направленные на их социализацию. 
Академия также проводит мероприятия по присвоению учёной степени доктора хабилитащуии (польск. - dr hab.), а также звания профессора богословских наук и звания почётного доктора.

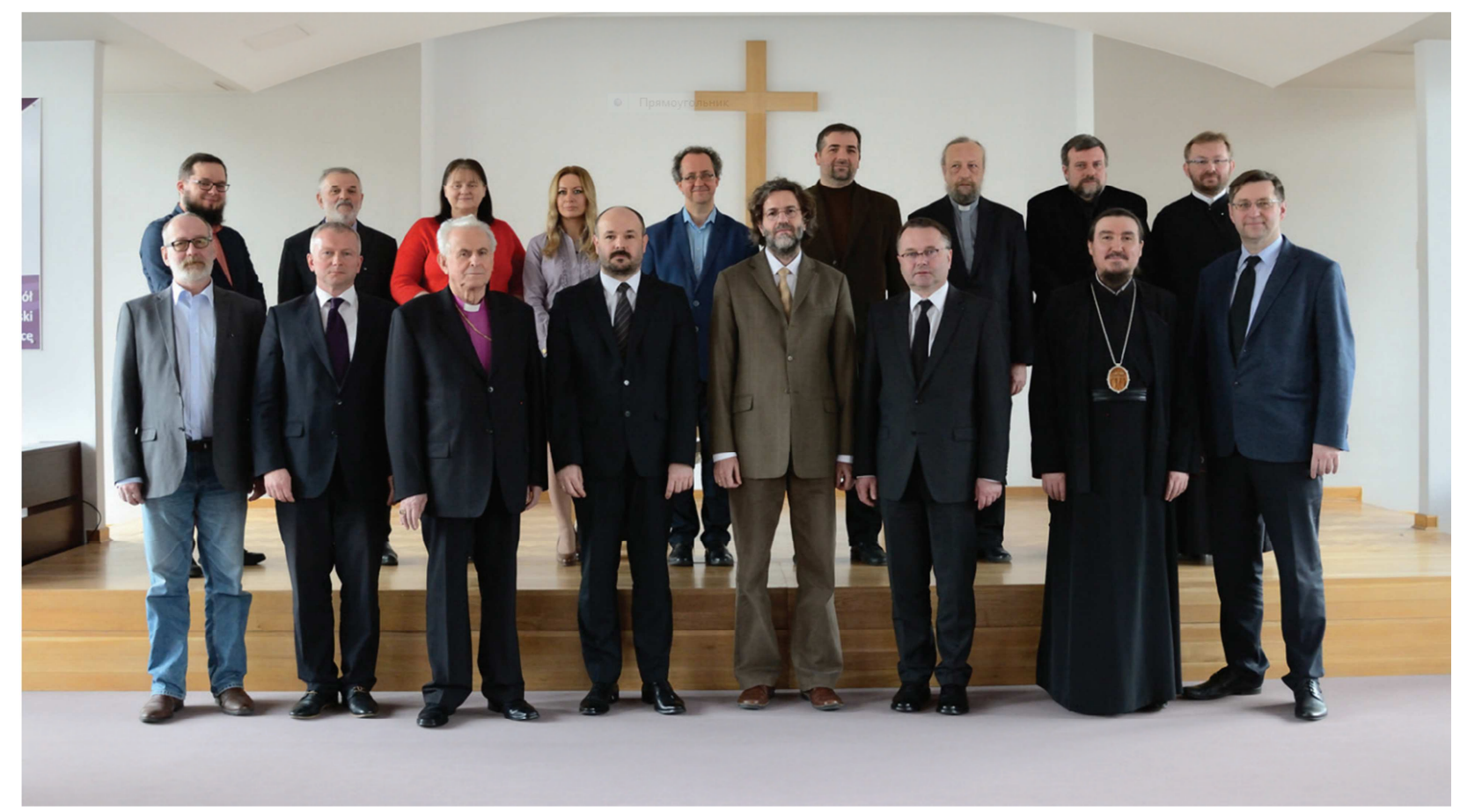

Рисунок 2 - Члены Совета Теологического факультета Христианской Теологической Академии в Варшаве, 2017. Фото Лукаш Трои [2, с. 11]

Первый ряд слева: проф., dr hab. Януш Т. Мацишко; проф., dr hab. Ержи Хинщ; проф., dr hab. Виктор Высочанский; декан теологического факультета, докт. проф. Ежи Остапчук; замдекана, проф., докт. Якуб Славик; ректор ChAT проф., dr hab. Богуслав Милерский; проректор, проф., dr hab. Ерджи Панковский; проф., проректор, dr hab. Тадеуш Я. Зелинский.

Второй ряд слева: докт. Ежси Сойка; проф., dr hab. Владимир Волосюк; магистр Барбара Каразевич; магистр Елена Квятковская; проф., dr hab. Борис Пшедпелский; проф., dr hab. Анджей П. Клучунский; проф., докт. Ержи Тофилюк; проф., dr hab. Рафал Лещинский; докт. Доротеуш Савицкий

Почётные докторские степени были присуждены многим выдающимся представителям научной и церковной жизни из Польши и из-за рубежа. В связи с 20-летием Христианской богословской академии в Варшаве Сенат и Совет академии присудили почётную степень доктора богословия honoris causa митрополиту Русской Православной Церкви Никодиму (Ротову) за большие заслуги в области экуменической и миротворческой деятельности [4]. Почётными докторами стали православные патриархи Константинополя Димитрий I и Варфоломей I, в 2004 г. - нынешний патриарх Московский и всея Руси Кирилл [5], архиепископ Афинский и всей Греции Христодул.

Профессор Курт Штальдер с факультета старокатолической теологии Бернского университета в 1993 г. получил в СhАТ вторую почётную степень. Почётными профессорами в Академии также стали: старокатолик Марбисинтос Мартин Уинский, Ян Антони Гласмейкер, епископ Кароль Котула - глава евангелической церкви Аугсбургского исповедания в Польше, епископ Курт Шарф - глава евангелической церкви БерлинБранденбург, о. профессор Герхард Заутер с факультета евангелической теологии Боннского университета, епископ Альфонс Носсол - председатель Польского епископального совета по

\footnotetext{
${ }^{1}$ Хабилита́ция (habilitation, от лат. habilis - способный, пригодный) в некоторых странах представляет собой процедуру получения высшей академической квалификации докторами философии, после которой претенденту присваивается учёная степень хабилитированного доктора.
} 
экуменизму, епископ проф. Вольфганг Хубер - евангелический епископ Берлина и Бранденбурга, председатель Совета Евангелической церкви Германии и другие деятели.

Главными приоритетами в деятельности Христианской теологической академии считают высокий уровень образования и мультикультурализм. Утверждая миссию Христианской Богословской Академии в постановлении Сената ChAT от 23 марта 2000 г., статус вуза был обозначен как «экуменический государственный университет, продолжатель факультета евангелической теологии и изучения православного богословия Варшавского университета». Как братское сообщество людей, которые ищут истину, добро и красоту, основываясь на вере в Иисуса Христа - university docentorum et scolarium - Академия, с одной стороны, является местом культивирования единства, с другой стороны, проявляет уважение к богословским различиям в христианских традициях. Обучая компетентных специалистов для нужд церковных меньшинств в Польше, университет сотрудничает и с римско-католическими теологическими факультетами Польши. Исследования в различных отраслях теологии соответствуют высоким научным стандартам и являются межкультурными в лучшем смысле этого слова.

Особенностью этого вуза считается его камерный характер, доверительные отношения между студентами и преподавателями, толерантность - ведь в стенах Академии учатся представители различных традиций, культур и религий. Именно по этой причине академия славится многочисленными международными связями. Символично, что в связи с празднованием 27 октября 2020 г. годовщины межрелигиозной встречи в Ассизи, ежегодный Варшавский молебен мира с участием представителей различных конфессий и религий (Примечание: инициатором мероприятия, впервые организованного в 1986 г., стал г. Папа Иоанн Павел II) в дистанционной форме прошёл именно в Христианской теологической академии.

Сегодня Христианская теологическая академия (Варшава) сотрудничает по договору о партнерстве с Евангелическо-богословским факультетом Боннского университета и со Старокатолическим факультетом Бернского университета. Кроме того, налажены тесные связи ChAT с православными колледжами Афин и Парижа, с Институтом евангельского богословия и религиозного образования Ольденбургского университета, а также с Московской духовной академией в Сергиевом Посаде [7]. Например, в ChAT в 2017 г. защитил докторскую диссертацию епископ Истринский, викарий Святейшего Патриарха Московского и всея Руси Серафим (Амельченков) [8].

В 2018 г. с Христианской теологической академией подписали соглашение о сотрудничестве Киевская духовная академия и семинария (Украина). Оно предусматривает совместные исследовательские и учебные проекты, конференции, обмен преподавателями и студентами.

Белорусские контакты с Академией носят, скорее, частный характер. В ChAT научную степень доктора теологии получили некоторые православные священники из Беларуси: в 2013 г. - архиепископ Гродненский и Волковысский Артемий; в 2014 г. председатель Синодального информационного отдела БПЦ, доцент кафедры апологетики Минской духовной академии прот. Сергий Лепин; в 2017 г. - секретарь Гродненской епархии прот. Анатолий Ненартович; в 2019 г. - благочинный Зельвенского округа Гродненской епархии прот. Георгий Суботковский [9] и другие священники.

Вуз, сравнимый по специализации с ChAT, в котором готовят специалистов по теологии, был создан в Беларуси в 2004 г. - это ГУО «Институт теологии имени свв. Мефодия и Кирилла» при БГУ, созданный на базе теологического факультета Европейского гуманитарного университета. Впервые в истории Восточной Европы специальность 1-21 0101 «Теология» была признана Министерством образования Республики Беларусь ещё в 1997 г., на следующий год после этого она была внесена в государственный стандарт на факультете теологии. Но, в отличие от дипломов белорусского института теологии, дипломы государственного образца СhАТ имеют международное признание.

Углубление партнёрских связей между христианскими конфессиями Польши и Беларуси может проходить в рамках обмена опытом по социально-педагогическому и аббилитическому служению, катехизации. Актуальность межконфессионального сотрудничества для Беларуси возрастёт в случае введения в системе начального и среднего образования обязательной религиоведческой дисциплины. 
В большинстве университетов Европы термин «теология» был заменён или включён в понятие «религиоведение». Церковные традиции больше не имеют определяющего значения при составлении учебных планов. Для государственной теологии неприемлема идея абсолютной церковной догмы. Для церковной теологии немыслима герменевтика, выходящая за рамки официальной догмы (как для Римской Католической церкви) или выходящая за рамки свидетельств библейских текстов для классических протестантов. Очень ценно, что на теологическом факультете Христианской теологической Академии студентов учат получать информацию и знания из современного контекста, который предопределён научными, экономическими и технологическими характеристиками, исследовать религиозные традиции с точки зрения герменевтического открытого и критического подхода, в условиях межконфессионального диалога и сотрудничества.

\section{Литература}

1. Lenczewski, M. Studium Teologii Prawosławnej na Uniwersytecie Warszawskim, 1925-1939. - Wydawnictwo ChAT, Warszawa 1992.

2. Baczyński, A., Sawicki D. 200 lat teologii uniwersyteckiej w Warszawie, Wydawnictwo

3. Никодим, митрополит (Ротов Борис Георгиевич) // Русская Православная Церковь. Официальный сайт Московского Патриархата [Электронный ресурс]. - Режим доступа : http://www.patriarchia.ru/db/text/1579224.html. - Дата доступа : 30.10.2020.

4. Биография Святейшего Патриарха Московского и всея Руси Кирилла // Русская Православная Церковь. Официальный сайт Московского Патриархата [Электронный pecypc]. - Режим доступа : http://www.patriarchia.ru/db/text/547091.html - Дата доступа : 30.10.2020.

5. Christliche Theologische Akademie Warschau [Электронный peсурс]. - Режим доступа : https://de.wikipedia.org/wiki/Christliche_Theologische_Akademie_Warschau - Дата доступа : 30.10.2020.

6. Серафим, епископ Истринский, викарий Святейшего Патриарха Московского и всея Руси (Амельченков Владимир Леонидович) // Русская Православная Церковь. Официальный сайт Московского Патриархата [Электронный ресурс]. - Режим доступа : http://www.patriarchia.ru/db/text/4017069.html - Дата доступа : 30.10.2020.

7. Гродненская епархия Белорусской Православной Церкви [Электронный ресурс]. Режим доступа : https://orthos.org/novostnye-tegi/hristianskaya-teologicheskaya-akademiya Дата доступа : 30.10.2020.

8. Bendza M ks., Dzieje Chrześcijańskiej Akademii Teologicznej w latach 1966 1989, w: Rocznik Teologiczny 2004.

Статья посвящена истории Христианской теологической академии в Варшаве (польск. Chrześcijańska Akademia Teologiczna w Warszawie, ChAT) - государственного межконфессионального высшего учебного заведения Польши. Изучен положительный опыт сотрудничества в этом вузе православной, Евангелической, старокатолическиой и других протестантских церквей в сфере образования, катехизации и абилитации с 1946 года по наши дни. Сделан вывод, что международные связи ChAT содействуют налаживанию межцерковного диалога и распространению экуменизма.

Ключевые слова: христианство, теология, Христианская теологическая академии в Варшаве, ChAT, межконфессиональных диалог.

The article is devoted to the history of the Christian Theological Academy in Warsaw (polish. Chrześcijańska Akademia Teologiczna w Warszawie, ChAT) is a state interfaith higher educational institution in Poland. The positive experience of cooperation in this university of the Orthodox, Evangelical, Old Catholic and other Protestant churches in the field of education, catechism and habilitation from 1946 to the present day has been studied. It is concluded that the international relations of ChAT contribute to the establishment of inter-Church dialogue and the spread of ecumenism.

Key words: Christianity, Theology, Christian Theological Academy in Warsaw, ChAT, interfaith dialogue. 